\title{
Demographic characteristics and types of stroke in Southwestern Saudi Arabia, and the potential demand of neuro endovascular specialists
}

Ibrahim Alnaami, MD, FRCSC, Adel Alhazzani, FRCPC, FAAN, Ibrahim Alburaidi, MD, Mona Alkhayri, MD, Hani Dibssan, MD, Mohammed S. Alqahtani, MD, Mohammed Alqahtani, MD, Saleh Alqahtani, MD, Shehata F. Shehata, MBBCh, PhD, Ashraf Gaber, $M D, A B R$, Saeed A. Alqahtani, MD, ABPN.

\begin{abstract}
الأهداف : التعرف على الصفات السكانية وأنواع الجلطات الدماغية

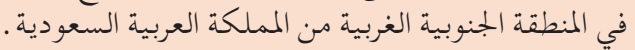

المنهجية : دراسة استرجاعية معتمدة على سجالات المستشفى حيث

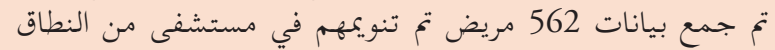

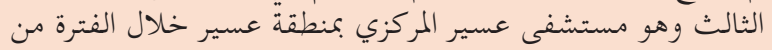

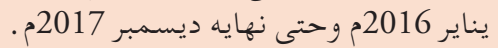

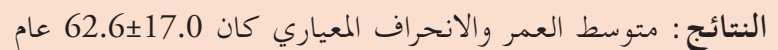

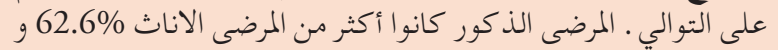

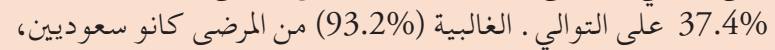

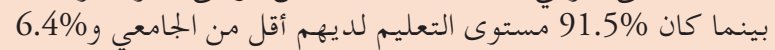

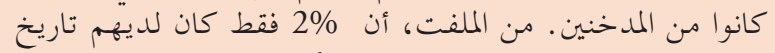

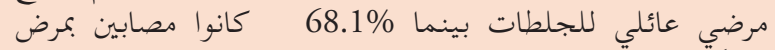

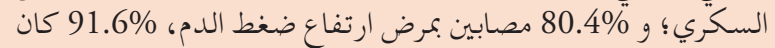

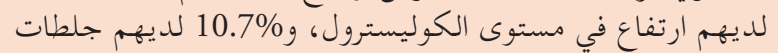

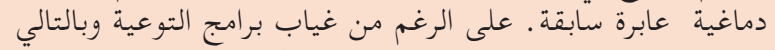

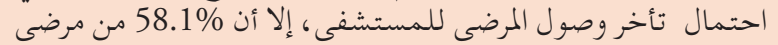

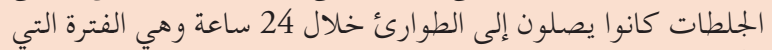

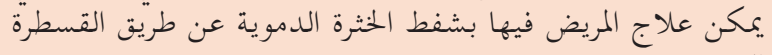
العصبية .

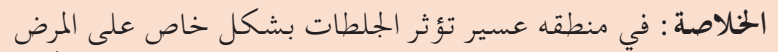

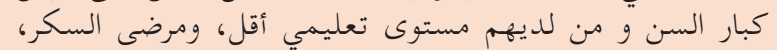

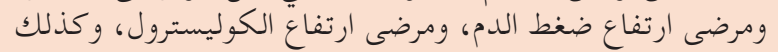

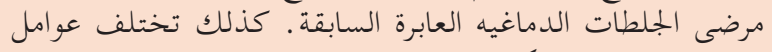
خطورة الجلطات بشكل كبير بحسب جنسية المرضى.
\end{abstract}

Objectives: To identify demographic characteristics, and types of stroke in Southwestern (Aseer) Region, Saudi Arabia.

Methods: This study is a retrospective and hospitalbased. The data of all stroke patients $(\mathrm{n}=562)$ admitted to the tertiary care hospital in the province, Aseer Central Hospital (ACH) within the period from January 2016 until December 2017 are included.

Results: The mean \pm SD of stoke patients' age was 62.6 \pm 17.0 years. Male patients were more than female patients (62.6\% and $37.4 \%$, respectively). The majority (93.2\%) were Saudi, while $91.5 \%$ had below university education and $6.4 \%$ were smokers. Interestingly, only $2 \%$ of patients had a family history of stroke, while $68.1 \%$ were diabetic, $80.4 \%$ were hypertensive, $91.6 \%$ had high serum cholesterol level, and $10.7 \%$ had history of transient ischemic attacks (TIA). Despite the lack of awareness, and leading to delay in reaching health care facility, $58.1 \%$ of stroke patients, were arriving to emergency department (ED) in less than 24 hours (potential endovascular therapeutic window).

Conclusions: In Aseer Region, Saudi Arabia, stroke affects mainly those who are older, less educated, diabetic, hypertensive, with hypercholesterolemia and previous history of TIA. Associated factors for stroke differ significantly according to their nationality.

Neurosciences 2021; Vol. 26 (1): 62-68 doi: 10.17712/nsj.2021.1.20200104

From the Division of Neurosurgery (Alnaami, Alburaidi, Alkhayri, Dibssan, Alqahtani S, Alqahtani M), Department of Surgery, from the Department of Family and Community Medicine (Shehata), from the Division of Neurology (Alqahtani S), Department of Medicine, College of Medicine, King Khalid University, from the Department of Radiology (Gaber), Aseer Central Hospital, Abha; from the Division of Neurology (Alhazzani), Department of Medicine, College of Medicine, King Saud University, Riyadh, from the Division of Neurology (Alqahtani MS), Armed forces Hospital-Southern Region, Aseer, Kingdom of Saudi Arabia, and from the High Institute of Public Health (Shehata), Alexandria, Egypt

Received 21st June 2020. Accepted 10th September 2020.

Address correspondence and reprint request to: Dr. Ibrahim Alnaami, Division of Neurosurgery, Department of Surgery, College of Medicine, King Khalid University, Abha, Kingdom of Saudi Arabia. E-mail:ialnaami@gmail.com

ORCID ID: https://orcid.org/0000-0001-6433-1990 
A cross the globe, stroke is now one of the most common leading causes for morbidity and mortality in adult patients after myocardial infarctions. Together with neoplasm, and myocardial infarctions, the 3 are top causes for death in the developed countries. Even when survive, a major portion of affected patients may suffer lifelong consequences in the form of physical or mental disabilities, which may result in social and economic challenges at the personal level and the society level.' Two types of brain stroke exist, hemorrhagic and ischemic. There has been more than a 100\% rise in stroke incidence in limited-resources countries. ${ }^{2}$ Stroke is one of the top 3 leading causes of death in the United States of America (USA). Approximately, 140,000 fatalities per year are caused by stroke in the USA. In year 2000, stroke resulted in 15,409 deaths (7\%) of all deaths in Canada. ${ }^{3}$ As per statistics of the World Health Organization, ${ }^{4}$ almost 15 million annual cases of stroke are recorded worldwide. One third of stroke patients dies and another third remains disabled for the rest of their lives. Indonesian Basic Health Research for instance, estimated that the prevalence of stroke in Indonesian population is somewhere around 12.1 per million whereas in China, the prevalence of stroke somewhere around 2.21\%.

In order to prevent and minimize the catastrophic sequelae of stroke, early detection is the main key as well as, determining the type of stroke, which is an essential element in clinical care of stroke patients. History and physical examination can provide a great help in distinguishing the type of stroke; ${ }^{5,6}$ however, evolving diagnostic images are the main keys in sorting stroke types. 7 The incidence of stroke is known to increase as age increases, more specifically, after the age of 45 years, the incidence gets doubled every decade of life. More than $70 \%$ of the strokes are occurring in patients who are 65 years or older. ${ }^{8}$ Men ( 1 in 5) tend to have higher lifetime risk of stroke than women (1 in 6). Men tend to have more risk of stroke at younger age than women, where women have higher rates of stroke at older age as they tend to have longer life expectancy than men. ${ }^{9}$ Stroke is increasing rapidly in the area of the Middle East. ${ }^{10}$ Some studies done in this part of the world, to look for the stroke associated factors and found that age, hypertension, previous stroke or history of transient ischemic attack (TIA), diabetes mellitus,

Disclosure. Authors have no conflict of interests, and the work was not supported or funded by any drug company. hypercholesterolemia, smoking, and atrial fibrillation are the major ones. ${ }^{1}$ Some national studies have found that patients with diabetes mellitus, hypertension, or high cholesterol are more vulnerable for stroke ${ }^{11}$ and the prevalence of 178 in every 100,000, was reported in the Eastern region of Saudi Arabia. ${ }^{12}$ Similar to other parts of the world, stroke burden is rapidly evolving and becoming a major cause of illness and deaths in Saudi Arabia. Akbar and Mushtaq ${ }^{13}$ found that stroke is more frequent in patients at their sixth decade of life with clear male predominance in Saudi Arabia. According to Almekhlafi's hospital based study, ${ }^{14}$ stroke burden is increasing in Saudi Arabia. Out of 548 patients in the study, stroke and its consequences contributed to $32 \%$ of the mortality.

In 2014, Robert and Zamzami ${ }^{1}$ reported that only 8 centers of 350 hospitals all around Saudi Arabia, are providing stroke thrombolytic therapy, and 2 out of these 8 centers have stroke code teams. However, by 2019, 8 more centers developed stoke code teams, and more hospitals-initiated stroke thrombolysis therapy. The present study aimed to identify demographic characteristics, clinical findings, and types of stroke in Aseer Region, Saudi Arabia.

Methods. In this hospital-based retrospective study, the data of all patients diagnosed with stroke within the period from January 2016 to December 2017 were included. An Excel data sheet for data collection, was made by the research team to obtain data from hospital charts in Aseer Central Hospital (ACH).

The variables consisted of demographic data, including age, gender, nationality, marital status, and education level. Also, the past medical history of diabetes mellitus, hypertension, cardiac diseases, family history of stroke, time of stroke onset, arrival to emergency department time, time of computed tomography (CT) of the brain, type of the stroke based on diagnosis on discharge note. Ethical approval was obtained from the King Khalid University IRB committee. After data collection, the data were entered and analyzed using the Statistical Package for Social Sciences Version 25 (Armonk, NY: IBM Corp.). Descriptive and inferential statistics were calculated. Chi-square test was utilized to measure the significant difference at $5 \%$ of the level of significance.

Results. A total of 562 stroke patients were included in this study. Table 1 depicts that the mean \pm SD of their age was $62.6 \pm 17.0$ years, with $45.7 \%$ of stroke patients between 60 and 80 years of age. Male patients were more than female patients $(62.6 \%$ and $37.4 \%$, ). 
The majority (93.2\%) were Saudi, while 91.5\% had below university education and $6.4 \%$ were smokers. Interestingly, only $2 \%$ of patients had a family history of stroke, while $68.1 \%$ were diabetic, $80.4 \%$ were hypertensive, $91.6 \%$ had high serum cholesterol level, and $10.7 \%$ had transient ischemic attacks.

Table 2 shows that stroke subtypes among our patients were either large artery vessel disease (35.6\%) or cardioembolic $(37.5 \%)$, while $11 \%$ had small vessel disease (lacunar). The stroke subtype was undetermined among $2.5 \%$ and of multiple causes among $13.3 \%$. Only $3.2 \%$ of the patients had intracranial hemorrhage. The time from the stroke onset until the arrival to the emergency department was less than 5 hours among $8.4 \%$ of patients, $5-12$ hours among 9.8\%, 13-24 hours among 39.9\% and more than 24 hours among $42 \%$ (Figure 1). The duration from the arrival to ED until

Table 1 - Bio-demographic characteristics of embolic stroke patients in Aseer Region, Saudi Arabia.

\begin{tabular}{|c|c|c|}
\hline Characteristics & $\mathrm{n}$ & $\%)$ \\
\hline $\begin{array}{l}\text { Age in years } \\
\quad<40 \text { years } \\
\quad 40-59 \\
60-79 \\
\quad \geq 80\end{array}$ & $\begin{array}{r}50 \\
163 \\
257 \\
92\end{array}$ & $\begin{array}{r}(8.9) \\
(29.0) \\
(45.7) \\
(16.4)\end{array}$ \\
\hline Mean \pm SD & 62.6 & 17.0 \\
\hline $\begin{array}{l}\text { Gender } \\
\text { Male } \\
\text { Female }\end{array}$ & $\begin{array}{l}352 \\
210\end{array}$ & $\begin{array}{l}(62.6) \\
(37.4)\end{array}$ \\
\hline $\begin{array}{l}\text { Nationality } \\
\quad \text { Saudi } \\
\text { Non-Saudi }\end{array}$ & $\begin{array}{r}524 \\
38\end{array}$ & $\begin{array}{r}(93.2) \\
(6.8)\end{array}$ \\
\hline $\begin{array}{l}\text { Education } \\
\text { Below university } \\
\text { University / higher }\end{array}$ & $\begin{array}{r}514 \\
48\end{array}$ & $\begin{array}{r}(91.5) \\
(8.5)\end{array}$ \\
\hline $\begin{array}{l}\text { Cigarette smoking } \\
\text { Yes } \\
\text { No }\end{array}$ & $\begin{array}{r}36 \\
526\end{array}$ & $\begin{array}{r}(6.4) \\
(93.6)\end{array}$ \\
\hline $\begin{array}{l}\text { Family history of stroke } \\
\text { Yes } \\
\text { No }\end{array}$ & $\begin{array}{r}11 \\
551\end{array}$ & $\begin{array}{r}(2.0) \\
(98.0)\end{array}$ \\
\hline $\begin{array}{c}\text { Diabetes } \\
\text { Yes } \\
\text { No }\end{array}$ & $\begin{array}{l}373 \\
179\end{array}$ & $\begin{array}{l}(68.1) \\
(31.9)\end{array}$ \\
\hline $\begin{array}{l}\text { Hypertension } \\
\text { Yes } \\
\text { No }\end{array}$ & $\begin{array}{l}452 \\
110\end{array}$ & $\begin{array}{l}(80.4) \\
(19.6)\end{array}$ \\
\hline $\begin{array}{l}\text { Hypercholesterolemia } \\
\text { Yes } \\
\text { No }\end{array}$ & $\begin{array}{r}47 \\
515\end{array}$ & $\begin{array}{r}(8.4) \\
(91.6)\end{array}$ \\
\hline $\begin{array}{l}\text { Transient ischemic attac } \\
\text { Yes } \\
\text { No }\end{array}$ & $\begin{array}{r}60 \\
502\end{array}$ & $\begin{array}{r}(10.7) \\
(89.3)\end{array}$ \\
\hline
\end{tabular}

Table 2 - Stroke related data of stroke patients in Aseer region, Saudi Arabia.

\begin{tabular}{lrr}
\hline Stroke data & $\mathbf{n}$ & $(\%)$ \\
\hline Stroke subtypes & & \\
$\quad$ Large vessel disease & 200 & $(35.6)$ \\
$\quad$ Cardioembolic & 211 & $(37.5)$ \\
$\quad$ Lacunar (small vessels disease) & 62 & $(11.0)$ \\
$\quad$ Undetermined & 14 & $(2.5)$ \\
$\quad$ Multiple causes & 75 & $(13.3)$ \\
Time from onset to arrival to emergency & & \\
department (hours) & & \\
$\quad<4.5$ & 47 & $(8.4)$ \\
$4.5-12$ & 55 & $(9.8)$ \\
$13-24$ & 224 & $(39.9)$ \\
$>24$ & 236 & $(42.0)$ \\
Time from arrival to emergency & & \\
department to CT scan (hours) & & \\
$\quad<1$ & & \\
$1-3$ & 90 & $(16.0)$ \\
$>3-6$ & 58 & $(10.3)$ \\
$>6$ & 82 & $(14.6)$ \\
& 332 & $(58.1)$ \\
\hline
\end{tabular}

undergoing CT imaging was more than 6 hours among $58.1 \%$ of stroke patients, the duration ranged from more than 3 hours to 6 hours for $14.6 \%$, while only $16 \%$ presented within less than one hour and $10.3 \%$ presented within 1-3 hours (Figure 2).

Table 3 shows that the modal age for the incidence of stroke differed significantly according to patients' nationality, being younger among non-Saudi as compared to Saudi patients (40-59 years and 60-79 years, respectively, $p<0.001)$. There were significantly more males among non-Saudi (84.2\%) than Saudi patients $(61.1 \%) \quad(p=0.004)$. There were significantly less married among non-Saudi (81.6\%) than Saudi patients $(95.8 \%)(p<0.001)$. There were significantly more smokers among non-Saudi $(15.8 \%)$ than Saudi $(5.7 \%)$ patients $(p=0.014)$. There were significantly fewer diabetics among non-Saudi $(42.1 \%)$ than Saudi $(70 \%)$ patients $(p<0.001)$. However, there were no significant differences among stroke patients regarding educational status, family history of stroke, hypertension, hypercholesterolemia or transient ischemic attacks according to their nationality.

Discussion. The idea of the study came out initially as a document to convince stake holders in the regional health affairs, to allocate more resources towards stroke treatment in the southwestern region, including and not limited to primary prevention, acute stroke unit, neuro endovascular service, and so forth. Therefore, a 2-year hospital-based retrospective study included 562 stroke patients who were admitted to $\mathrm{ACH}$, Aseer 


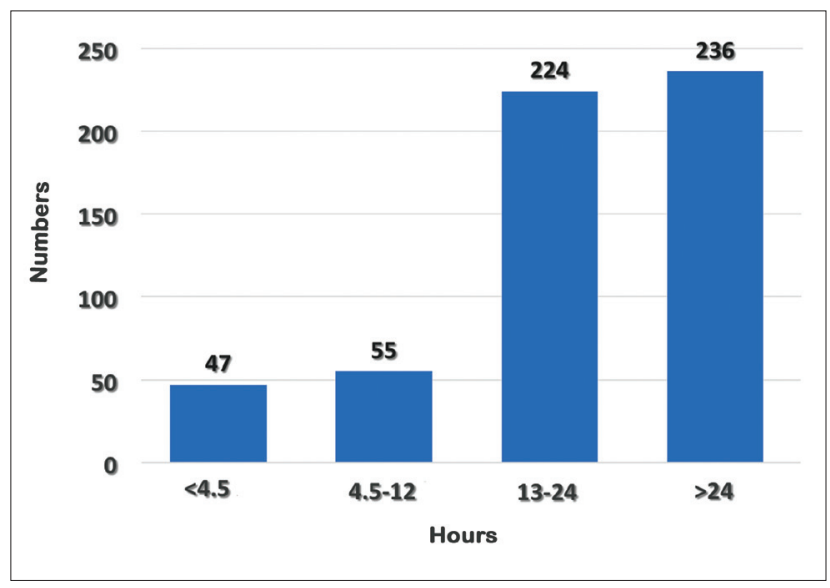

Figure 1 - Presentation time from the onset of stroke symptoms until the arrival to emergency department (in hours) among stroke patients in Aseer Region, Saudi Arabia.

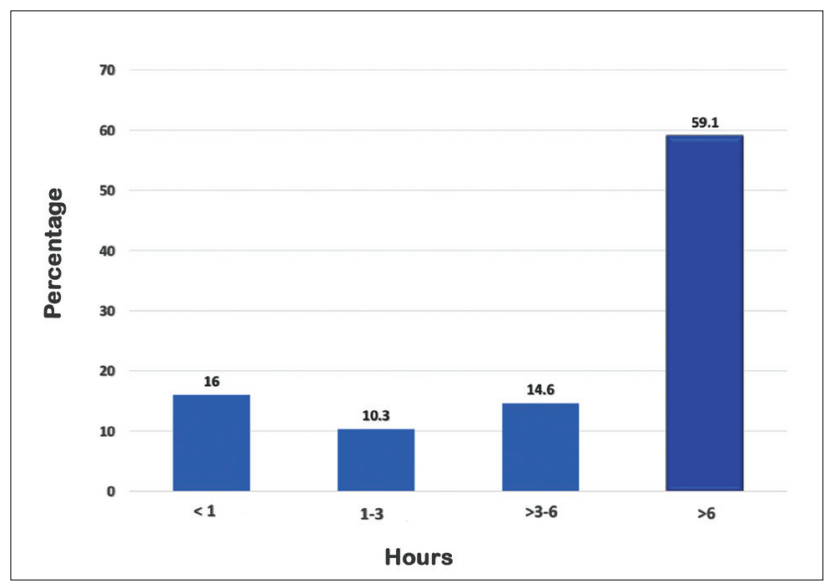

Figure 2 - Presentation time from stroke onset of symptoms till undergoing CT (in hours) among stroke patients in Aseer Region, Saudi Arabia.

Region, Saudi Arabia. This study highlighted certain characteristics for stroke patients, which may reflect certain associated factors for stroke and its residual functional disability in Aseer Region.

Our stroke patients' mean age was above 60 years, with almost half of them aged 60-80 years. Moreover, almost two-thirds of the patients were males. As age is recognized as one of the top associated factors for stroke, ${ }^{15}$ Akbar and Mushtaq ${ }^{13}$ noted that stroke is seen more between the age of 50 and 60 year, with male predominance in both Saudi nationals and expatriates. Saudi local studies ${ }^{16}$ showed that stroke was more common in the seventh decade of life, and others reported that same finding of the former study in regards the age;
Table 3 - Risk factors of stroke according to patients' nationality.

\begin{tabular}{|c|c|c|c|c|c|}
\hline Characteristics & & tudi & $\begin{array}{r}\text { Non } \\
(\mathbf{n}\end{array}$ & $\begin{array}{l}\text { Saudi } \\
\text { 38) }\end{array}$ & $P$-value \\
\hline $\begin{array}{l}<40 \\
40-59 \\
60-79 \\
\geq 80\end{array}$ & $\begin{array}{r}47 \\
134 \\
253 \\
90\end{array}$ & $\begin{array}{r}(9.0) \\
(25.6) \\
(48.3) \\
(17.2)\end{array}$ & $\begin{array}{r}3 \\
29 \\
4 \\
2\end{array}$ & $\begin{array}{r}(7.9) \\
(76.3) \\
(10.5) \\
(5.3)\end{array}$ & \\
\hline $\begin{array}{l}\text { Gender } \\
\text { Male } \\
\text { Female }\end{array}$ & $\begin{array}{l}320 \\
204\end{array}$ & $\begin{array}{l}(61.1) \\
(38.9)\end{array}$ & $\begin{array}{r}32 \\
6\end{array}$ & $\begin{array}{l}(84.2) \\
(15.8)\end{array}$ & 0.004 \\
\hline $\begin{array}{l}\text { Marital status } \\
\text { Married } \\
\text { Not married }\end{array}$ & $\begin{array}{r}502 \\
22\end{array}$ & $\begin{array}{r}(95.8) \\
(4.2)\end{array}$ & $\begin{array}{r}31 \\
7\end{array}$ & $\begin{array}{l}(81.6) \\
(18.4)\end{array}$ & $<0.001$ \\
\hline $\begin{array}{l}\text { Educational status } \\
\text { Below university } \\
\text { University }\end{array}$ & $\begin{array}{r}481 \\
43\end{array}$ & $\begin{array}{r}(91.8) \\
(8.2)\end{array}$ & $\begin{array}{r}33 \\
5\end{array}$ & $\begin{array}{l}(86.8) \\
(13.2)\end{array}$ & 0.292 \\
\hline $\begin{array}{l}\text { Cigarette smoking } \\
\text { Yes } \\
\text { No }\end{array}$ & $\begin{array}{r}30 \\
494\end{array}$ & $\begin{array}{r}(5.7) \\
(94.3)\end{array}$ & $\begin{array}{r}6 \\
32\end{array}$ & $\begin{array}{l}(15.8) \\
(84.2)\end{array}$ & 0.014 \\
\hline $\begin{array}{l}\text { Family history of } \\
\text { stroke } \\
\quad \text { Yes } \\
\text { No }\end{array}$ & $\begin{array}{r}9 \\
515\end{array}$ & $\begin{array}{r}(1.7) \\
(98.3)\end{array}$ & $\begin{array}{r}2 \\
36\end{array}$ & $\begin{array}{r}(5.3) \\
(94.7)\end{array}$ & 0.128 \\
\hline $\begin{array}{c}\text { Diabetes } \\
\text { Yes } \\
\text { No }\end{array}$ & $\begin{array}{l}367 \\
157\end{array}$ & $\begin{array}{l}(70.0) \\
(30.0)\end{array}$ & $\begin{array}{l}16 \\
22\end{array}$ & $\begin{array}{l}(42.1) \\
(57.9)\end{array}$ & $<0.001$ \\
\hline $\begin{array}{l}\text { Hypertension } \\
\text { Yes } \\
\text { No }\end{array}$ & $\begin{array}{r}425 \\
99\end{array}$ & $\begin{array}{l}(81.1) \\
(18.9)\end{array}$ & $\begin{array}{r}30 \\
8\end{array}$ & $\begin{array}{l}(78.9) \\
(21.1)\end{array}$ & 0.743 \\
\hline $\begin{array}{l}\text { Hypercholesterolemia } \\
\text { Yes } \\
\text { No }\end{array}$ & $\begin{array}{r}26 \\
498\end{array}$ & $\begin{array}{r}(5.0) \\
(95.0)\end{array}$ & $\begin{array}{r}4 \\
34\end{array}$ & $\begin{array}{l}(10.5) \\
(89.5)\end{array}$ & 0.141 \\
\hline $\begin{array}{l}\text { Transient ischemic } \\
\text { attacks } \\
\text { Yes } \\
\text { No }\end{array}$ & $\begin{array}{r}56 \\
468\end{array}$ & $\begin{array}{l}(10.7) \\
(89.3)\end{array}$ & $\begin{array}{r}4 \\
34\end{array}$ & $\begin{array}{r}(0.5) \\
(89.5)\end{array}$ & 0.975 \\
\hline
\end{tabular}

Values are expressed as number and percentage (\%).

however, the frequency was least in the 30-40 years of age group. In Saudi, the stroke prevalence is higher in men in comparison to women. ${ }^{18}$ Similar findings were published by many other papers. ${ }^{11,19,20}$ Only $2 \%$ of our patients had a family history of stroke, and $6.4 \%$ were smokers, while most of our patients had below university levels of education. Many other reports have found that stroke associated factors include unhealthy lifestyle for example, smoking and a family history of stroke. ${ }^{19,21}$ Some studies have found that $18.2 \%$ of stroke patients had a positive family history. They noted that a family history of stroke combines genetic and environmental factors. The relation between family history and stroke was not statistically significant, whereas sibling's history 
was more associated with stroke compared to parental history. Moreover, the difference between sibling history and parental history decreased even further after the adjustment for other variables, which may shed light on the effect of common environment to the sibling history of stroke.

A non-linear association between patients' level of education and their stroke risk have been reported. ${ }^{23}$ Such finding is consistent with those concluded by several existing studies in the USA, ${ }^{24,25}$ Sweden, ${ }^{26}$ Italy, ${ }^{27}$ and Denmark. ${ }^{28}$ The present study identified that several disease conditions are commonly associated with stroke, namely, diabetes, hypertension, hypercholesterolemia, and transient ischemic attack (TIA). This finding is in accordance with those reported by several studies. Robert and Zamzami ${ }^{1}$ ascribed age, hypertension, previous stroke or TIA, diabetes mellitus, hypercholesterolemia, and smoking as the major associated factors for stroke in the area Middle East. Similarly, Awada and Al Rajeh ${ }^{11}$ and Kelly and Robert ${ }^{21}$ reported that associated factors for stroke include hypertension, diabetes mellitus, hyperlipidemia, and TIA.

Our study revealed that the time from the stroke onset, until the arrival to the ED for most patients (81.1\%), was more than 12 hours. Moreover, the duration from the arrival to ED until undergoing CT imaging was more than 6 hours among $58.1 \%$ of stroke patients: the duration ranged from more than 3 hours to 6 hours for $14.6 \%$, while only $16 \%$ presented within less than one hour and $10.3 \%$ presented within $1-3$ hours. A Nigerian study, ${ }^{29}$ reported that none of their stroke patients came to seek medical care in less than 3 hours of the symptom's onset. A thorough history and imaging usually exclude other causes of deficit apart from stroke and a brain CT brain is usually considered as the first line imaging modality that helps to distinguish ischemic from hemorrhagic stroke. Neuroimaging is the mainstay in directing thrombolytic and interventional therapy for stroke patients. Meaningful outcome can only be procured within a time frame as short as 4 and half hours of symptom's onset for thrombolytic therapy.

Several studies indicated that patients' lack of knowledge in regards to stroke can be one of the most important factors leading to delay in presentation. ${ }^{30-32}$ Obviously, major attention and actions have to be taken towards addressing factors leading to delay in stroke management, at pre and in-hospital levels, by the national health authorities. ${ }^{33}$

The duration from the onset of stroke symptoms until undergoing CT imaging, was more than 6 hours in more than half of patients, while only approximately $25 \%$ of patients presented and had their neuroimaging within 3 hours from the onset of their stroke symptoms. Major efforts not only include patients' awareness, but also more of physicians' awareness towards stroke's treatment, and the establishment of a pathway of stroke patients are mandated to overcome the delay in obtaining proper timely imaging and eventually proper treatment. This delay in obtaining images of stroke patients is anticipated in a trauma busy center where most of the resources are directed towards that. Another important fact is that the authors think that, the slow progress of stroke treatment in the era preceding the mechanical thrombectomy, had left an impact on physicians, that nothing significant can be added to stroke patients especially if they are out of the IV t-PA window. Despite the above, $58 \%$ of patients come within the potential therapeutic window of mechanical thrombectomy, which gives an indicator of the growing need of neuro interventionists to treat stroke patients, to have such service available 24/7.34,35

Results of the present study showed that the main stroke subtypes among our patients were either large artery disease or cardioembolic. High prevalence rates of large artery disease were also reported by several studies. A recent Saudi study, reported the prevalence of large artery disease causing stroke was $27 \%,{ }^{36}$ while in Beirut, Lebanon, it was at $54 \%{ }^{37}$ In the area of the Middle-East and North Africa, Al Rukn et al ${ }^{38}$ reported $46 \%$. It is obvious that our finding of the large artery disease $(35 \%)$ in our population lies within the spectrum in the studies above.

Findings of the present study showed that associated factors for stroke among our patients differed significantly according to their nationality. Non-Saudi patients were significantly younger, males, unmarried, cigarette smokers and non-diabetic. The significant variability in associated factors may be attributed to genetic, racial or environmental differences between the Saudi and non-Saudi populations. Nowadays, it is accepted fact in stroke world, that the etiology is multifactorial. ${ }^{22,39}$

Primary preventive actions should focus on modifiable associated factors of stroke, namely, smoking, diabetes, hypertension, and hypercholesterolemia. Moreover, since the modification of associated factors (for example quitting smoking) remains a primary management strategy for effective prevention of stroke, in addition to community-based studies that direct and establish a plan of action for stroke prevention have the best chance to minimize the devastating impact of stroke. ${ }^{8}$ Secondary prevention should be enforced by raising the public's awareness regarding warning and early symptoms of stroke and the importance of prompt 
transfer to ED and an immediate referral of suspected cases for diagnosis by CT neuroimaging, potential candidacy of IV t-PA, and neuro endovascular service.

Study limitations. Despite the large number of patients in our study, which is fair to consider generalizability of the results to the Saudi population, despite that, the fact of missing some data of some patients is a limiting factor, in addition to the potential of discrepancy between the treating team member in determining the type of stroke based on work up, however, the authors considered the discharge summary as a conclusion of the opinions of all treating teams. The potential selection bias is limited by including all the patients with complete data for the study duration.

In conclusion, the study revealed that in Aseer Region, Saudi Arabia, stroke affects mainly those who are older (aged above 60 years), less educated, diabetic, hypertensive, with hypercholesterolemia and TIA. There is an unduly late arrival to the hospital and referral for CT neuroimaging of most stroke patients. Associated factors for stroke differ significantly according to their nationality.

Therefore, the primary prevention of stroke should start by the management of its modifiable associated factors (for example quitting smoking, control of diabetes, hypertension and high serum cholesterol). Secondary prevention can be applied by raising the public's awareness regarding stroke for early identification and immediate transfer to the hospital. Despite the late presentation of stroke patients, major percentage of them are presenting within the potential endovascular therapeutic window.

Acknowledgment. The authors would like to acknowledge proofreadingservices.com for English language editing of the manuscript

\section{References}

1. Robert AA, Zamzami MM. Stroke in Saudi Arabia: a review of the recent literature. The Pan African Medical Journal 2014; 17: 14 .

2. Kamalakannan S, Gudlavalleti ASV, Gudlavalleti VSM, Goenka S, Kuper H. Incidence \& prevalence of stroke in India: a systematic review. The Indian Journal of Medical Research 2017; 146: 175-185.

3. The Internet Stroke Center. Stroke Statistics. [cited 2020]. Available from: http://www.strokecenter.org/patients/aboutstroke/stroke-statistics/

4. World Health Organization. Stroke, Cerebrovascular accident. [cited 2020]. Available from: http://www.emro.who.int/ health-topics/stroke-cerebrovascular-accident/index.html

5. Ojaghihaghighi S, Vahdati SS, Mikaeilpour A, Ramouz A. Comparison of neurological clinical manifestation in patients with hemorrhagic and ischemic stroke. World J Emerg Med 2017; 8: 34-38.
6. Wang W, Tang X, Liu W, Jia K, Zhao X, Yu F. Clinical features of embolic stroke of undetermined source. Front Neurol 2020; 11: 58.

7. Ojaghihaghighi S, Vahdati SS, Mikaeilpour A, Ramouz A. Comparison of neurological clinical manifestation in patients with hemorrhagic and ischemic stroke. World J Emerg Med 2017; 8: 34-38.

8. Thrift AG, Thayabaranathan T, Howard G, Howard VJ, Rothwell PM, Feigin VL, et al. Global stroke statistics. Int J Stroke 2017; 12: 13-32.

9. Roy-O'Reilly M, McCullough LD. Age and sex are critical factors in ischemic stroke pathology. Endocrinology 2018; 159: 3120-3131.

10. El-Hajj M, Salameh P, Rachidi S, Hosseini H. The epidemiology of stroke in the Middle East. Eur Stroke J 2016; 1: 180-198.

11. Alharbi MN, Alharbi AK, Alamri MA, Alharthi AAS, Alqerafi AM, Alharbi MN. Ischemic stroke: prevalence of modifiable risk factors in the Saudi population. IJMDC 2019; 3: 601-603.

12. Alahmari K, Paul SS.Prevalence of stroke in Kingdom of Saudi Arabia - through a physiotherapist diary. Mediterranean Journal of Social Sciences 2016; 7: 1 S1.

13. Akbar DH, Mushtaq M. Clinical profile of stroke: The experience at King Abdulaziz University hospital. J Sci Res Med Sci 2001; 3: 35-38.

14. Almekhlafi MA. Trends in one-year mortality for stroke in a tertiary academic center in Saudi Arabia: a 5-year retrospective analysis. Ann Saudi Med 2016; 36: 197-202.

15. Boehme AK, Esenwa C, Elkind MSV. Stroke Risk Factors, Genetics, and Prevention. Circ Res 2017; 120: 472-495.

16. Al Jadid MS, Robert AA. Determinants of length of stay in an inpatient stroke rehabilitation unit in Saudi Arabia. Saudi Med J 2010; 31: 189-192.

17. Al Eithan MH, Amin M, Robert AA. The effect of hemiplegia/ hemiparesis, diabetes mellitus, and hypertension on hospital length of stay after stroke. Neurosciences (Riyadh) 2011; 16: 253-256.

18. Memon I, Abu-Shaheen A, Heena H, Al-Tannir M. Point prevalence study for stroke in Saudi Arabia: A cross-sectional survey. Saudi J Health Sci 2019; 8: 93-97.

19. Yi X, Luo H, Zhou J, Yu M, Chen X, Tan L, et al. Prevalence of stroke and stroke related risk factors: a population based cross sectional survey in southwestern China. BMC Neurol 2020; 20: 5 .

20. Musa N, Khan A, Ayub S. Stroke risk factors in public sector hospitals, Peshawar. Journal of Gandhara Medical and Dental Science 2020; 6: 30-35.

21. Chung JW, Kim BJ, Han MK, Kang K, Park JM, Park SS, et al. Family history and risk of recurrent stroke. Stroke 2016; 47 : 1990-1996.

22. Tian T, Jin G, Yu C, Lv J, Guo Y, Bian Z, et al. Family history and stroke risk in China: Evidence from a large cohort study. $J$ Stroke 2017; 19: 188-195.

23. Jackson CA, Sudlow CLM, Mishra GD. Education, sex and risk of stroke: a prospective cohort study in New South Wales, Australia. BMJ Open 2018; 8: e024070.

24. Avendano M, Kawachi I, Van Lenthe F, Boshuizen H, Mackenback J, Bos V, et al. Socioeconomic status and stroke incidence in the US elderly: the role of risk factors in the EPESE study. Stroke 2006; 37: 1368-1373. 
25. Liu L, Xue F, Ma J, Ma M, Long Y, Newschaffer CJ. Social position and chronic conditions across the life span and risk of stroke: a life course epidemiological analysis of 22,847 American adults in ages over 50. Int J Stroke 2013; 8 (Suppl A100): 50-55.

26. Kuper H, Adami HO, Theorell T, et al. The socioeconomic gradient in the incidence of stroke: a prospective study in middle-aged women in Sweden. Stroke 2007; 38: 27-33.

27. Veronesi G, Ferrario MM, Chambless LE. Gender differences in the association between education and the incidence of cardiovascular events in Northern Italy. Eur J Public Health 2011; 21: 762-767.

28. Andersen KK, Steding-Jessen M, Dalton SO, Olsen TS. Socioeconomic position and incidence of ischemic stroke in Denmark 2003-2012: a nationwide hospital-based study. J Am Heart Assoc 2014; 3: e000762.

29. Ogbole GI, Owolabi MO, Ogun O, Ogunseyinde OA, Ogunniyi A. Time of presentation of stroke patients for CT imaging in a Nigerian tertiary hospital. Ann Ib Postgrad Med 2015; 13: 23-28.

30. Saengsuwan J, Suangpho P, Tiamkao S. Knowledge of Stroke Risk Factors and Warning Signs in Patients with Recurrent Stroke or Recurrent Transient Ischaemic Attack in Thailand. Neurol Res Int 2017; 2017: 8215726.

31. Arulprakash N, Umaiorubahan M. Causes of delayed arrival with acute ischemic stroke beyond the window period of thrombolysis. J Family Med Prim Care 2018; 7: 1248-1252.

32. Saengsuwan J, Suangpho P. Self-perceived and Actual Risk of Further Stroke in Patients with Recurrent Stroke or Recurrent Transient Ischemic Attack in Thailand. J Stroke Cerebrovasc Dis 2019; 28: 632-639.
33. Ashraf VV, Maneesh M, Praveenkumar R, Saifudheen K, Girija AS. Factors delaying hospital arrival of patients with acute stroke. Ann Indian Acad Neurol 2015; 18: 162-166.

34. Albers GW, Marks MP, Kemp S, Christensen S, Tsai JP, Ortega-Gutierrez S, et al. Thrombectomy for stroke at 6 to 16 hours with selection by perfusion imaging. NEngl J Med 2018; 378: 708-718.

35. Nogueira RG, Jadhav AP, Haussen DC, Bonafe A, Budzik RF, Bhuva P, et al Thrombectomy 6 to 24 hours after stroke with a mismatch between deficit and infarct. N Engl J Med 2018; 378: 11-21.

36. Al Khathaami AM, Aldriweesh MA, Al Bdah BA, Alhasson MA, Alsaif SA, Alluhidan WA, et al. Anterior circulation large vessel occlusion stroke in Saudi Arabia: Prevalence, predictors, and outcome. J Stroke Cerebrovasc Dis 2020; 29: 105080.

37. Lahoud N, Abbas MH, Salameh P, Salen N, Abes S, Hosseini $\mathrm{H}$, et al. A retrospective analysis of 254 acute stroke cases admitted to two university hospitals in Beirut: classification and associated factors. Funct Neurol 2017; 32: 41-48.

38. Al Rukn S, Mazya MV, Hentati F, Ben Sassi S, Nabli F, Said Z, et al. Stroke in the Middle-East and North Africa: a 2-year prospective observational study of stroke characteristics in the region-results from the Safe Implementation of Treatments in Stroke (SITS)-Middle-East and North African (MENA). International Journal of Stroke 2019; 0: 1-8.

39. Chauhan G, Debette S. Genetic Risk Factors for Ischemic and Hemorrhagic Stroke. Curr Cardiol Rep 2016; 18: 124.

\section{Clinical Practice Guidelines}

Clinical Practice Guidelines must include a short abstract. There should be an Introduction section addressing the objective in producing the guideline, what the guideline is about and who will benefit from the guideline. It should describe the population, conditions, health care setting and clinical management/diagnostic test. Authors should adequately describe the methods used to collect and analyze evidence, recommendations and validation. If it is adapted, authors should include the source, how, and why it is adapted? The guidelines should include not more than 50 references, 2-4 illustrations/tables, and an algorithm. 